\title{
PEMBERDAYAAN MASYARAKAT MELALUI PEMBUDIDAYAAN DAN PENGOLAHAN MARKISAH BERBASIS POTENSI DAERAH UNTUK MENINGKATKAN PENDAPATAN KELUARGA
}

\author{
Jasminarni, Suandi, Trias Novita dan Evita \\ Universitas Jambi \\ E-mail: jasminarnidjanan@ymail.com
}

\begin{abstract}
ABSTRAK
Tujuan kegiatan KKN-PPM ini adalah untuk pemberdayaan masyarakat melalui pembudidayaan dan pengolahan markisah berbasis potensi daerah untuk meningkatkan pendapatan keluarga. KKN merupakan mata kuliah wajib di universitas jambi yang harus diikuti oleh setiap mahasiswa sebelum melaksanakan ujian akhir (skripsi) hal ini tertuang pada Peraturan Rektor Nomor: 1223/UN 21/DT/2013, tanggal 19 November 2013. Pelaksanaan program KKN-PPM menggunakan metoda utama berupa pelatihan, demonstrasi dan demplot kepada kelompok sasaran. Mahasiswa yang sudah diberi pembekalan akan mendampingi kelompok sasaran selama pelatihan dan pelaksanaan KKN-PPM. Langkah-langkah operasional yang akan dilakukan selama program KKN-PPM secara terinci adalah sebagai berikut pemilihan anggota masyarakat yang akan dibina pada dua desa, analisis pengetahuan masyarakat tentang tanaman markisah dan pengenalan pada mereka usaha budidaya dan pengolahan markisah, pemberian pelatihan manajemen pada masyarakat membuat, mengatur dan menjaga unit budidaya dan pengolahan markisah, pelatihan dan demontrasi pembuatan unit budidaya dan pengolahan markisah dengan memanfaatkan lahan pekarangan yang dilakukan oleh mahasiswa didampingi Dosen Pembimbing Lapangan (DPL). Target kegiatan KKN-PPM adalah metode dan produk: (1) Perbaikan teknik budidaya markisah sehingga dapat menghasilkan produksi yang optimum, sehingga terjadinya peningkatan pendapatan masyarakat. (2) Memanfaatkan lahan pekarangan sebagai lahan budidaya markisah, sehingga dapat dimanfaatkan sebagai bahan baku pengolahan panganan yang dapat menambah nilai jual markisah yang dibudidayakan. (3) Terjadinya perbaikan sistem budidaya markisah tanpa mengikuti persyaratan budidaya menjadi mengikuti syarat yang semestinya. (4) Pengolahan aneka panganan berbahan baku markisah sebagai oleh-oleh sehingga dapat menambah pendapatan masyarakat. (5) Terjadinya peningkatan partisifasi masyarakat melalui pembinaan yang dilakukan dan pelatihan pembuatan panganan berbahan baku markisah seperti dodol markisah dan sirup markisah.. Kegiatan KKN-PPM akan dilaksanakan di dua desa di Kecamatan Keliling Danau yaitu Desa Koto Baru dan Desa Koto Agung. Metode kegiatan yang dilakukan dalam pemberdayaan kelompok sasaran adalah metode partisipasif dan aksi yang melibatkan kelompok sasaran dibagi dalam 2 kelompok pengembangan budidaya tanaman markisah dan 2 kelompok pengolahan markisah menjadi berbagai produk penganan. Selain itu, masyarakat secara umum diikutkan dalam kegiatan ini. Mahasiswa bertindak sebagai fasilisator. Materi yang diberikan melalui pembelajaran orang dewasa (andragogi), dengan rasio $30 \%$ teori dan $70 \%$ praktek.
\end{abstract}

Kata kunci: Markisah, dodol dan sirup markisah

\section{PENDAHULUAN}

Kecamatan Keliling Danau merupakan daerah yang terdapat disepanjang danau Kerinci, dengan ketinggian tempatnya kira-kira 1000-1600 diatas permukaan laut, berhawa sejuk dengan curah hujan cukup tinggi. Dilihat dari keadaan iklimnya maka sangat cocok untuk budidaya markisah dimana tanaman markisah cocok ditanam pada daerah dengan ketinggian tempat $700-2.000$ mdpl butuh suhu dan kelembaban yang tinggi.

Selain itu Kecamatan Keliling Danau ini terletak di pinggiran danau Kerinci yang merupakan salah satu objek wisata yang terdapat di kabupaten Kerinci, sebagai daerah kunjungan wisata lokal maupun manca Negara. Daerah ini sangat memerlukan oleh-oleh yang bisa digunakan sebagai buah tangan pengunjung. Oleh-oleh yang berupa penganan sudah banyak di kembangkan di Kabupaten Kerinci seperti dodol kentang dari Siulak dan dodol labu dari Tanjung.

Di salah satu desa yang diambil sebagai lokasi KKN-PPM yaitu Desa Koto Agung dimana di Desa ini lahan pekarangan yang dimiliki oleh masyarakat sebagian besar terdapat banyak pohon markisah. Markisah yang tumbuh ini belum dibudidayakan sesuai syarat budidaya yang seharusnya sehingga produksi yang dihasilkan belum optimal. Selain itu buah markisah yang dihasilkan kurang disukai karena rasa buahnya yang asam dan belum mempunyai nilai jual, sehingga akhirnya busuk dan terbuang.

Buah markisah dengan rasa asam ini dapat diolah menjadi dodol dan sirup markisah serta jenis makanan yang lainnya. Olahan markisah ini bisa dijadi oleh-oleh bagi wisatawan yang berkunjung ke Danau Kerinci sehingga 
dapat menumbuhkan UKM baru di Desa Koto Agung dan Desa Koto Baru Kecamatan Keliling Danau, sehingga pada akhirnya dapat menjadi usaha keluarga dalam meningkatkan kesejahteraan keluarga.

Pengembangan budidaya markisah dan pengolahannya merupakan usaha agroindustri yang memiliki potensi besar untuk dikembangkan karena dapat peningkatan penghasilan petani dan pertimbangan kesehatan, karena kandungan nutrisi dalam buah markisah. Perlu diketahui, tanaman markisah banyak memberikan manfaat bagi manusia. Isi buah markisa bisa dimanfaatkan untuk sari buah atau ekstrak buah atau puree (bahan dasar untuk membuat sirup markisa), biji markisa yang telah dikeringkan dapat dimanfaatkan untuk minyak atsiri juga. Kulit markisa yang dibuang setelah isinya dipakai untuk puree dapat digunakan untuk makanan ternak setelah difermentasi terlebih dahulu. Bisa dibayangkan betapa tingginya nilai ekonomis tanaman markisa ini.

Budidaya markisah dapat dilakukan dalam skala kecil untuk industri rumah tangga, karena tidak memerlukan tempat yang luas atau sebagai usaha sampingan keluarga yang nantinya mampu memberikan tambahan pendapatan keluarga. Buah markisah dapat diolah menjadi penganan yang bernilai jual tinggi sehingga sangat membantu dalam memperbaiki ekonomi keluarga. Diharapkan pengembangan budidaya dan pengolahan markisah di Desa Koto Agung dan Desa Koto Baru, Kecamatan Keliling Danau akan memberikan prospek yang bagus dan dapat meningkatkan pendapatan keluarga.

Pemilihan lokasi KKN-PPM di Desa Koto Agung dan Desa Koto Baru adalah karena adanya permintaan masyarakat setempat,tim pengusul sudah menempatkan mahasiswa KKN - PPM di kecamatan Keliling Danau selama 2 tahun berturut-turut pada tahun 2015 dan 2016 (tema KKN-PPM waktu itu: Pemberdayaan masyarakat melalui pengembangan budidaya belut Kerinci sebagai bahan baku pengolahan makanan khas Kerinci di kecamatan Keliling Danau (tahun 2015 dan Pemanfaatan limbah gergaji kayu dan sekam padi sebagai media jamur tiram dalam rangka peningkatan kesejahteraan masyarakat pedesaan (2016)) disamping itu juga melihat kondisi lahan sekitar rumah mereka yang belum termanfaatkan dengan baik.

Program ini diharapkan dapat membantu masyarakat dalam hal memanfaatkan potensi semua yang ada dilingkungan mereka. Pada akhirnya dapat membantu masyarakat yang sebagian besar bermata pencaharian sebagai nelayan dan petani (padi sawah dan hortikultura) dalam membudidayakan markisah dan mengolahnya menjadi penganan, sehingga dapat memperbaiki dan meningkatkan perekonomian masyarakat. Dalam hal ini tentunya sangat memerlukan pemikiran serta tenaga dari berbagai disiplin ilmu. Oleh sebab itu diusulkan program KKN-PPM di daerah ini untuk dapat membantu permasalahan yang ada.

Markisah biasa dijual dalam bentuk buah tanpa diolah, melalui program KKN-PPM diharapkan dapat dilakukan diversifikasi produk olahan markisah, sehingga dapat menambah aneka penganan yang dapat dijual sebagai oleh-oleh bagi wisatawan yang berkunjung ke objek wisata Danau Kerinci. Pada akhirnya usaha ini diharapkan akan lebih membantu untuk meningkatkan perekonomian masyarakat desa setempat.

\section{METODE YANG DIGUNAKAN}

Kegiatan pemberdayaan dilakukan dengan metode partisipasif dan aksi yang melibatkan masyarakat kelompok sasaran yang berjumlah antara 15 - 20 orang dibagi dalam 2 kelompok untuk pengembangan budidaya markisah. Masing-masing kelompok terdiri dari satu orang ketua kelompok dan 8 - 10 orang anggota. Sedangkan kelompok sasaran untuk pengolahan makanan berbahan baku markisah berjumlah antara 15 - 20 orang yang dibagi menjadi 2 kelompok, masing-masing kelompok terdiri dari $8-10$ orang. Mahasiswa bertindak sebagai fasilisator.

Materi yang diberikan melalui pembelajaran orang dewasa (andragogi), dengan rasio 30\% teori dan 70\% praktek. Oleh karena proses pembelajaran mengikuti pembelajaran orang dewasa, sehingga selama pelatihan dan pendampingan berlangsung lebih menitikberatkan pada peningkatan kualitas hidup mereka, memberikan ketrampilan, keahlian dan kemampuan untuk memecahkan masalah yang mereka alami dalam kehidupan bermasyarakat. Oleh sebab itu pada akhir pembelajaran diharapkan kelompok sasaran akan mampu mengarahkan diri sendiri, mampu membuka peluang usaha dan mampu menjadi guru untuk dirinya sendiri dan kelompok.

\section{HASIL YANG DICAPAI}

Sebelum adanya mahasiswa KKN-PPM di lokasi Desa Koto Baru dan Desa Koto Agung, masyarakat desa Koto Agung belum mengenal tentang budidaya markisah, markisah yang ada didesa adalah markisah yang tumbuh liar. Namun setelah adanaya KKN-PPM di desa ini masyarakat mulai mengenal cara budidaya markisah, manfaatnya dan juga cara pengolahannya sehingga bisa dijadikan sebagai salah satu sumber penambah pendapatan keluarga dan untuk pemenuhan gizi keluarga.

Pelatihan diberikan dalam bentuk penyuluhan dan demonstrasi tentang cara pembibitan, pemeliharaan sampai pada pengolahan hasil penyuluhan dan pembimbingan setiap minggunya pada masing-masing desa.

Kelompok ibu-ibu dilatih membuat berbagai makanan yang menggunakan markisah sebagai bahan bakunya. Sampai saat ini ibu-ibu telah mempraktekkan beberapa macam cara pengolahan yang bisa disimpan cukup lama seperti pembuatan dodol dan sirup markisah. 


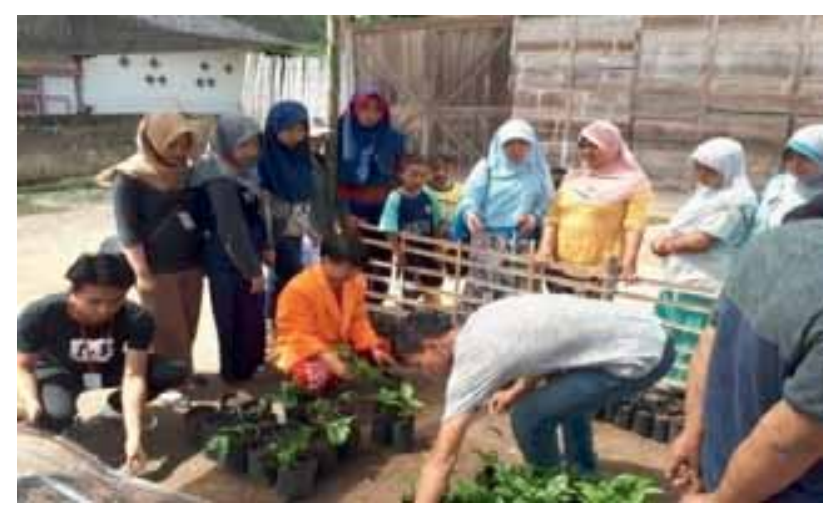

Gambar 1. Pelatihan pembibitan

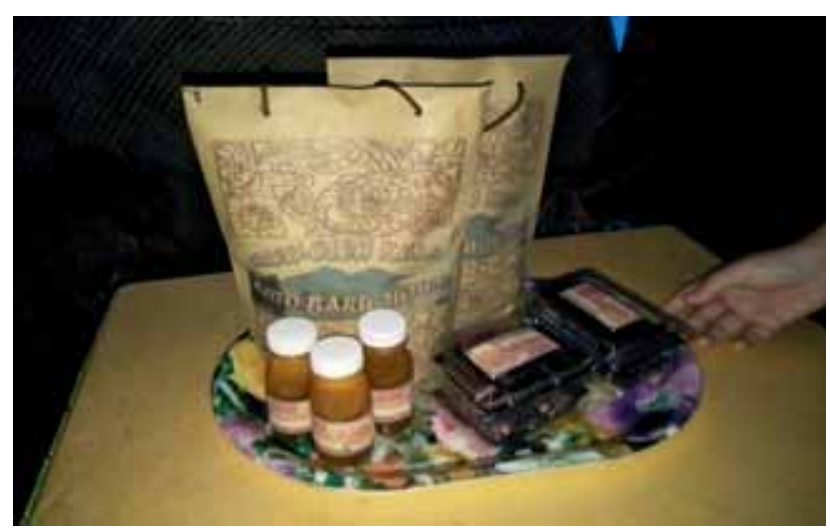

Gambar 3. Sirup Markisah

Masyarakat banyak terlibat dalam melakukan kegiatan yang diberikan, mereka bersemangat dalam memelihara pembibitan markisah dan membenahi tanaman markisah yang sudah ada di halaman mereka. Semula markisah didesa ini kurang dapat dimanfaatkan dengan baik oleh masyarakat karena rasanya yang asam., tapi dengan adanya pengolahan markisah menjadi berbagai bentuk makanan olahan markisah yang tidak termanfaatkan dapat digunakan sebagai bahan pembuatan panganan dan minuman yang bergizi baik untuk keluarga maupun sebagai sumber tambahan pendapatan keluarga.

\section{KESIMPULAN}

1. Terjadi peningkatan pengetahuan teknik pembudidayaan markisa bagi kelompok mitra,

2. Terjadi peningkatan pengetahuan dan wawasan pemeliharaan tanaman markisa pada lahan pekarangan,

3. Kelompok mitra mendapatkan pengetahuan dan keterampilan pengolahan buah markisa untuk aneka panganan sehingga dapat menambah pendapatan keluarga

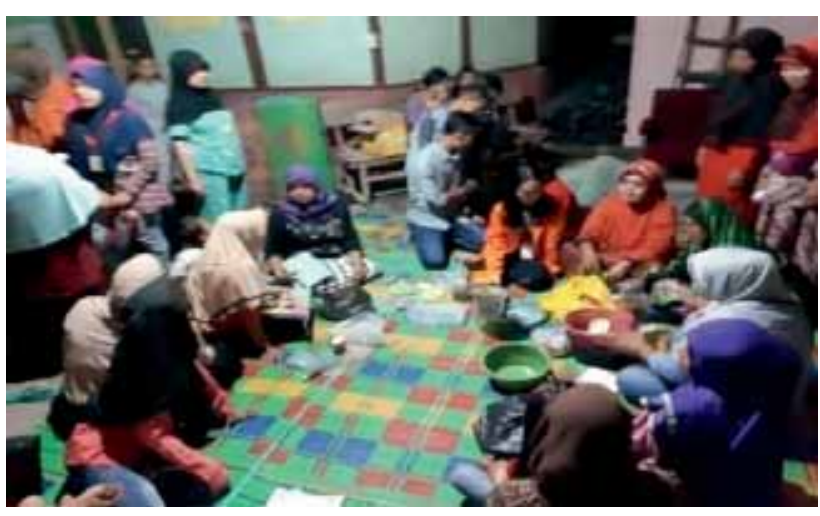

Gambar 2. Pelatihan pengolahan produk

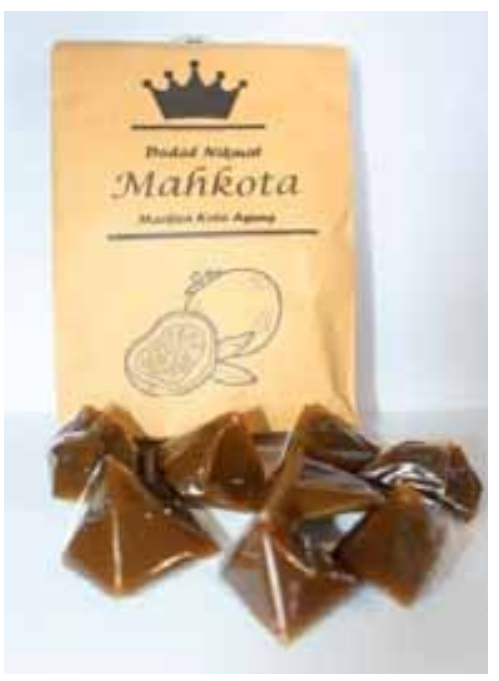

Gambar 4. Dodol markisah

\section{UCAPAN TERIMA KASIH}

Direktorat Jenderal Penguatan Riset dan Pengembangan (c.q Direktorat Riset dan Pengabdian Masyarakat - DRPM) DIKTI.

\section{DAFTAR PUSTAKA}

Ashari, Sumeru. 2006. Hortikultura Aspek Budidaya. Jakarta: UI Press

Hermani dan Mono. R. 2006. Tanaman Berkhasiat Anti Oksidan. Penebar swadaya: Jakarta.

Hutagalung, L, dkk. 1996. Petunjuk Teknis Teknologi Menunjang Agribisnis Markisa asam Di Sumatera Utara. Medan: Badan Penelitian dan Pengembangan Pertanian Balai Pengkajian Teknologi Pertanian Gedong Johor.

Rusmunandar, 1986. Mengenal Tanaman Buah - buahan. Bandung: Sinar Baru Semangun, Haryono. 2000. Penyakit - penyakit Tanaman Hortikultura di Indonesia Yogyakarta: Gajah Mada University Press.

Tjitrosoepomo, G. 2007. Taksonomi Tumbuhan

(Spermatophyta). Yogyakarta: Gajah Mada 